\title{
Intercambios virtuales: comentarios en línea, un nuevo género de comunicación
}

Virtual interactions: online comments, a new genre of

\section{communication}

\author{
Emiliano Andrés Calomarde emiliano.mdq@hotmail.com \\ http://orcid.org/0000-0003-3995-3354 \\ Universidad Nacional de Mar del Plata (Argentina)
}

\section{Resumen}

Esta reseña se realiza a partir del análisis del libro Reading the comments: likers, haters and manipulators at the bottom of the web publicado en 2015, producto del trabajo de Joseph Reagle, especialista en estudios sobre internet. En este libro el autor esbozará las principales características y usos de los comentarios en línea, entendiendo a estos como un género de comunicación cada vez más presente en la vida cotidiana de las personas y en los estudios sociales.

Palabras clave: Comentarios en línea; comunicación; interacción social.

\section{Abstract}

This review is based on the analysis of the book Reading the comments: likers, haters and manipulators at the bottom of the web, published in 2015, product of the work of Joseph Reagle, specialist in studies on the Internet. In this book, the author will outline the main 
features and uses of online comments, understanding it as a gender of communication increasingly present in the daily life of peopl and in social studies.

Keywords: Online comments; communication; social interactions.

Nuestro mundo está impregnado de comentarios. En la era digital, la comunicación ha encontrado en la web un ámbito más amplio para la circulación de la información y el despliegue de diversidad de ideas y opiniones. La contracara de este proceso es un medio propenso al conflicto, el abuso y la discriminación. En Reading the comments: likers, haters and manipulators at the bottom of the web, Joseph Reagle se propone analizar los comentarios en línea como un género discursivo reactivo, breve y asincrónico (puede no haber necesariamente una coincidencia temporal entre los intercambios) que se configura como una forma de interacción social cada vez más frecuente de la vida contemporánea. De su carácter irascible y reaccionario abundan los ejemplos: el día de los enamorados de 2013 el campeón paralímpico Oscar Pistorius asesinó a su novia de cuatro disparos: muchos comentaristas se lamentaron de no poder cortar sus piernas como castigo. Como sostiene Reagle, las secciones de comentarios pueden llenarse rápidamente con publicaciones vergonzosas, motivo por el cual no faltan quienes señalan la improductividad o inutilidad de los mismos.

En esta obra, el autor parte de la premisa de que el análisis de estas conversaciones ofrece una herramienta valiosa para aprender mucho sobre nuestras sociedades, pues la subjetividad individual y colectiva se ponen en juego en las interacciones virtuales. Reagle intenta rescatar al comentario como un aspecto marginado de la web pero presente en aquellas cosas que la gente común encuentra en su vida cotidiana. El autor muestra, con un conocimiento profundo de la web (sitios, léxico, personalidades) y una numerosa revisión de casos, la manera en que los comentarios pueden informar y mejorar nuestra vida en sociedad, abriendo canales novedosos de sociabilidad pero también manipular, alienar e incluso divertirnos o dejarnos perplejos. En los primeros dos capítulos el autor pretende introducir al análisis de los comentarios a partir de su definición y de su rastreo genealógico. Reagle los concibe como un género de comunicación social que se remite a un "otro" cuya reactividad es incontrolable, incierta y ubicua. Su carácter contextual lo coliga a un determinado espacio-temporal y a un objeto receptor, pero esta fina soga que lo ata al "contexto virtual" bien puede cortarse fácilmente puesto que el comentario es hipotextual. Como en cualquier otro tipo de interacción 
social, los agentes no salen ilesos en la lectura y respuesta de su contenido: un comentario puede afectar el estado de las personas, puede ayudarlas a tomar decisiones o inclusive puede alterar su comportamiento. En el capítulo dos, el autor realiza una revisión histórica de los comentarios a los fines de derribar la extendida idea de que se configuran como un fenómeno novedoso. Estos han heredado muchos modos del pasado. Formas de escritura anteriores a la era de la web están presentes allí, por ejemplo, las reseñas o los comentarios de puntuación. Lo más relevante es que si bien los comentarios de tipo informativo presentan un legado histórico, la escala y la ubicuidad actual no tienen comparación con ningún otro periodo.Por todo ello, los comentarios son un recurso muy útil y valioso por lo que también se encuentran sujetos a manipulación. A lo largo del tercer capítulo, el autor analiza las dinámicas que adoptan las farsas virtuales. Dicho examen habilita la inmersión en la peculiar lógica del lenguaje en la era digital (ciberlenguaje): desde los spam, fakes o sockpuppets, el autor hace visible la cuestión de la falsificación para conseguir mayor reputación o beneficios económicos. Gran parte de esto está impulsado por el actual deseo rapaz de calificar y clasificar todo. La mirada más pesimista de Reagle sale a la luz en este pasaje del libro, puesto que para él las redes sociales o el "gráfico social" no resolverán el problema de la manipulación, sino que nos tentarán a convertirnos en manipuladores con el fin de sacar provecho de las interacciones virtuales. Debido a la facilidad para opinar, en muchos casos de manera rápida e irreflexiva, el comentario es visto como una práctica potencialmente fallida. En el capítulo cuatro, Reagle estudia la forma en que los comentarios entre ciberagentes pueden sostenerse en una cultura de la retroalimentación (feedback). Este tipo de comentarios se destaca por su intención de ayudar a un receptor a lograr un objetivo, como puede ser un aficionado por la escritura a mejorar su producción literaria. Estos tipos de comentarios requieren, según Reagle, un "corazón valiente" y "orejas fuertes" tanto para los que publican como para los que leen los comentarios, ya que muchas veces al dar una opinión sobre el trabajo ajeno es fácil realizar generalizaciones muy amplias o presumir que los demás sienten lo mismo que uno. Los comentarios pueden ser muchas veces no deseados o solicitados. Esto nos liga directamente con otra cuestión fundamental: los comentarios también pueden propiciar sentimientos de inseguridad y alienación. En los capítulos restantes el autor se focaliza puntualmente en las reacciones que suscitan las interacciones virtuales en las subjetividades que participan de las comunidades virtuales. En primer lugar Reagle describe los "troles" y los "enemigos": las batallas intimidatorias y comentarios abusivos que a menudo se encuentran en línea. El autor enmarca esta cultura con los efectos del anonimato, la desindividualización y la despersonalización ofreciendo un conjunto de investigaciones sociales respecto a las 
repercusiones de la virtualidad sobre los sujetos. Estos comentarios, atenuados por cuestiones raciales o de género, no parecen ir en disminución y su intangibilidad provoca ansiedad y conflictos. La cuestión del odio y el acoso no son, en consecuencia, de fácil solución. No obstante, para Reagle más que ignorarlos es preferible conservarlos e identificarlos como comportamientos que no deben ser bienvenidos por las comunidades. La reacción virtual de los "otros", reflejada en los innumerables comentarios a los que estamos expuestos, deja huellas que moldean la subjetividad. Esta cuestión será analizada en el capítulo seis. En el compartir cotidiano que habilita el medio virtual elaboramos un sentido de "nosotros" que está sujeto al comentario y a la mirada de los demás. Ahora las personas tienen una amplia gama de identidades para elegir y una multitud de formas para lograrlas y compararse. Según Reagle, la era digital abre la posibilidad de una comparación social constante puesto que las personas pueden observan hacia un marco externo y obtener una sensación de sí mismos. Si el ser humano como ser social siempre está en presencia de un "otro" y actuando para un público, las consecuencias del uso de las tecnologías y la omnipresencia propia del comentario afectan de maneras disímiles las subjetividades.En el capítulo siete Reagle pretende mostrar que el comentario además de informar y alienar puede ser confuso, divertido y desconcertante, tal como lo evidencia la exclamación textual "WTF" (traducida como ¿qué diablos?), un acrónimo que se ha convertido en parte del léxico por el cual los comentaristas expresan su desconcierto o sorpresa. Los comentarios también son caóticos, reveladores y extraños. El autor ofrece una serie de casos que permiten corroborar esta faceta en las cuales marcos de sentidos divergentes confluyen en un mismo ámbito. La convergencia de significados disímiles en torno a cualquier aspecto del mundo social permite dar cuenta que el mundo de los comentarios está atravesado por el desconcierto, los absurdos y las sorpresas. Desde sus inicios los comentarios en línea han venido configurando un nuevo tipo de vinculación social. En efecto, amplía la capacidad heurística para el conocimiento del mundo social. Es inútil darles la espalda en tanto se configuran como una característica propia de la vida contemporánea. En la era de la web 2.0 las personas pueden hacer comentarios desde la sala de estar, la oficina y la calle a través de clics, texto, imágenes, audios y videos. El ámbito virtual se erige como un medio en el que los agentes ponen en juego su propia subjetividad y en el que se edifican aspectos primordiales para su accionar cotidiano, desde sutiles detalles cada vez más naturalizados como la compra de una mercancía hasta la configuración de aspectos identitarios. De la misma manera, como en todos los ámbitos de interacción, la potencialidad de los conflictos también se hace presente aunque eyectados con mayor fuerza por la propia dinámica del mundo virtual. Las fortalezas y debilidades de tales conversaciones exigen a los 
científicos sociales hacer caso omiso a las indicaciones de no leer las conversaciones y los debates presentes en la web.

\section{Bibliografía}

Reagle Jr., J. M. (2015). Reading the Comments: Likers, Haters, and Manipulators at the Bottom of the Web. Cambridge, MA: MIT Press. 